DOI https://doi.org/10.18551/rjoas.2018-11.34

\title{
ECONOMIC EVALUATION OF BIOURIN LIQUID ORGANIC FERTILIZER IN THE VILLAGE OF PAYA TUNGEL OF CENTRAL ACEH REGENCY, INDONESIA
}

\author{
Andriani Rini* \\ Graduate Study Program of Agribusiness, Syiah Kuala University, Banda Aceh, Indonesia
}

Kasimin Suyanti, Bakar Yusya Abu

Faculty of Agriculture, Syiah Kuala University, Banda Aceh, Indonesia

*E-mail: riniandriani.bptp@gmail.com

\begin{abstract}
Many efforts have been made by the peasant community in improving their standard of living, including by making farmer groups to increase the capacity of individuals in the group. In the district of Central Aceh there are several active farmer groups that still hope for assistance from related parties in terms of advancing their efforts to increase income.One of the empowerments carried out to improve the standard of living of farmers in Central Aceh District is to evaluate the related economic business of biourin liquid fertilizer. The raw material for biourin liquid organic fertilizer business is obtained by utilizing local resources that are around, namely the urine of cattle.Making the process of liquid organic fertilizer, this biourin produces an average number of products as much as 110 liters in a single production process, with a selling price of Rp. 60,000 per liter. It can be seen that the R / C ratio of the biourin liquid organic fertilizer business is more than 1 that is equal to 4.34.Based on the results of the calculation of the Break Even Point (BEP) analysis shows that this biourin business will benefit if this business produces or sells more than 98.96 liters per production process. In each production process the amount of profit obtained is Rp. 4,617,500, - and the total investment is Rp. $1,382,500$. Of this amount, the ROI value is $3.34 \%$. The calculation results obtained a value added ratio in biourin products of 0.974 or $97.4 \%$.
\end{abstract}

\section{KEY WORDS}

Economic evaluation, empowerment, farmer groups, biourin liquid fertilizer.

The content of organic fertilizers as well as inorganic fertilizers each contain nutrients needed by plants, but nitrogen and other nutrients contained in organic fertilizers are released slowly so that their use must be sustainable, the value of fertilizer contained in organic fertilizers is also low and very varies, the supply of nutrients occurs slowly and provides limited amounts of nutrients (Sutanto, 2006).

Table 1 - Characteristics of Organic and Inorganic Fertilizers

\begin{tabular}{|l|l|l|}
\hline \multicolumn{1}{|c|}{ Chracteristics } & \multicolumn{1}{|c|}{ Organic Fertilizer } & \multicolumn{1}{|c|}{ Inorganic Fertilizer } \\
\hline Crop response & Slow & Fast \\
Target plants & Special-broad & Large \\
Provision of nutrients & Indirect & Directly \\
Relationship process withplant & Biological & Chemistry \\
Quality requirements & Generally not frozen yet & Standard \\
Environmental impact & No available & Available \\
\hline
\end{tabular}

Many efforts have been made by the peasant community in improving their standard of living, including by making farmer groups to increase the capacity of individuals in the group. In the district of Central Aceh there are several active farmer groups that still hope for assistance from related parties in terms of advancing their efforts to increase income.

Paya Tungel Village, Jagong Jeget District, Central Aceh District is an area that has the potential of livestock farming and processing of cattle waste in Central Aceh District. The 
raw material used is cow urine. The cattle waste processing business in Paya Tungel Village has been running for two years, starting in 2016. Beginning with the existence of livestock assistance from the government to 4 active farmer groups namely Bali cattle as many as 50 and 25 Brahman Cross.At present the cows are placed next to the house land of one of the heads of the farmer groups. To treat the cows, each member of the farmer group gets a picket schedule or daily grass feed, so that the cattle will not lack food.

The potential of farmers in Paya Tungel Village, Jagong Jeget Subdistrict, must be developed by conducting an economic evaluation and empowering farmer groups so that farmers in Paya Tungel Village, Jagong Jeget District can maximize profits. Economic evaluation functions so that farmers can find out the correct way of bookkeeping, knowing acceptance, profits, R / C Ratio, BEP, ROI, and value added analysis. From the results of the analysis, it is expected to provide insight for business makers in managing financial performance. In addition, it also needs to be seen how the empowerment of farmer groups in increasing business income of liquid organic fertilizer (biourin).

Identification and The Formulation of Problem How is the economic evaluation of the business of liquid organic fertilizer biourin in Paya Tungel Village, Central Aceh District?

\section{METHODS OF RESEARCH}

This research was conducted in Paya Tungel Village, Jagong Jeget District, Central Aceh District. The product of this business is liquid organic fertilizer (biourin). The method used in this research is survey method. The data used are qualitative and quantitative data. (Marshal, 1989) in the book Quantitative \& Qualitative Research Methods defines qualitative research as a process that tries to gain a better understanding of the complexity that exists in human interaction. The population in this study were all farmer groups who worked and used biourin products in Paya Tungel Village, Central Aceh District. Determination of sample respondents was done intentionally (purposive).

Profit Analysis. According to Soekartawi (1995), revenue and gross income are defined as the total product value in a period of time. While net income is the difference between revenue and total costs during the production process. While profit or income is the difference between total business revenue and total costs incurred. Methodologically revenues and profits can be notified as follows:

$$
\begin{gathered}
T C=T F C+T V C \\
T R=P \times Q \\
\pi=T R-T C
\end{gathered}
$$

Where: $P=$ Selling price $/$ unit $(R p) ; Q=$ Number of items produced (liters); TFC $=$ Total Fixed Cost (Rp); TVC = Total Variable Cost $(R p) ; \pi=$ Profit $(R p) ; T R=$ Total revenue (Rp); $\mathrm{TC}=$ Total cost $(\mathrm{Rp})$.

Soekartawi (1995) states that the R / C ratio is the ratio (ratio) between revenue and production costs. Following is the R / C Ratio formula:

$$
R C \text { Ratio }=\frac{T R}{T C}
$$

Conditions: If the $R$ / $C$ ratio is $>1$, then the business is feasible and profitable; If the $R$ / $C$ ratio $=1$, then the business is even or not profitable and does not lose; If the $R / C$ ratio is $<1$, then the business is not profitable.

Analysis of Break Even Point (BEP). According to Rahardi (1998), BEP is a form of analysis that shows the relationship between fixed costs, variable costs, profits, and minimal sales volume that must be maintained so as not to suffer losses. BEP values can be calculated using the following formula:

$$
\operatorname{BEP}(\text { Rupiah })=\frac{F C}{1-\frac{V C}{S}}
$$




$$
\operatorname{BEP}(\text { Unit })=\frac{F C}{P-V}
$$

Where: $F C=$ Fixed fee $(R p) ; V C=$ Variable Cost $(R p) ; S=$ net sales $(R p) ; P=$ Price per product unit (Rp); $V=$ variable cost per unit (Rp / unit).

BEP indicator: BEP Value (Rupiah) = The nominal amount of money that must be generated in order; the company is not profitable and does not lose; BEP Value (Unit) = The number of product units that the company must produce; the company is not profitable and does not lose.

Return On Investment (ROI) Analysis. Rahardi (1998) states that a business is also said to be efficient if the ROI value of the business is high. ROI is the value obtained by the entrepreneur from every money invested in his business in a certain period of time. ROI or analysis of the rate of return on capital that has been used to determine business profits related to the capital that has been issued. ROI calculations can be done using the following formula:

$$
\mathrm{ROI}=\frac{N p}{I} \times 100 \%
$$

Where: $\mathrm{ROI}=$ Return On Investment; NP = net profit (net profit); I = Investment $/$ capital; Indicator: The greater the ROI percentage, the better the ROI.

Value Added Analysis. According to Hayami (1990), there are two ways to calculate added value, namely value added for processing and value added for marketing.

Table 2 - Hayami Method Add Value Calculation Procedures

\begin{tabular}{|c|c|c|}
\hline $\mathrm{n} / \mathrm{n}$ & Calculation Element & Calculation Formula \\
\hline 1. & Production result & $\mathrm{a}$ \\
\hline 2. & Raw material & $\mathrm{b}$ \\
\hline 3. & Labor & $\mathrm{c}$ \\
\hline 4. & Conversion factor & $\mathrm{a} / \mathrm{b}=\mathrm{h}$ \\
\hline 5. & Labor coefficient (\%) & $\mathrm{c} / \mathrm{b}=\mathrm{i}$ \\
\hline 6. & Product price & $\mathrm{e}$ \\
\hline 7. & Average wage & $\mathrm{f}$ \\
\hline 8. & Raw material prices & $\mathrm{g}$ \\
\hline 9. & Another input & $\mathrm{h} \times \mathrm{d}=\mathrm{j}$ \\
\hline 10. & Production Value & $\mathrm{j}-\mathrm{f}-\mathrm{g}=\mathrm{k}$ \\
\hline 11. & a. Value-added & $\mathrm{k} / \mathrm{j}$ \\
\hline 12. & b. Added Value Ratio (\%) & $\mathrm{i} \times \mathrm{e}=\mathrm{m}$ \\
$\mathrm{m} / \mathrm{k}$
\end{tabular}

Source: Hayami, (1990).

\section{RESULTS AND DISCUSSION}

The raw material for the business of liquid organic fertilizer (biourin) was obtained by utilizing local resources around, namely the urine of cattle. This is due to the need to utilize existing resources so that they are not wasted. The source of these raw materials is utilized to the maximum extent possible because it will be able to support the expansion of employment opportunities, increase farmers' income, and be environmentally friendly. Aside from the raw material for cow urine, local fruits are also used which are processed into Local Micro Organisms (MOL) and spices that are around.

Production, Acceptance and Profit Costs. Production costs consist of identifying the amount of fixed costs and variable costs used in producing liquid organic fertilizer biourin. The making of this biourin liquid organic fertilizer process produces an average number of products as much as 110 liters in a single production process, with a selling price of Rp. $60,000,-$ / liter. Based on the results of calculations, the amount of profits from this business 
can be said to be relatively large or very profitable. Therefore, this biourin business is expected to continue to survive and develop.

Analysis of the $\mathrm{R} / \mathrm{C}$ ratio of the biourin liquid organic fertilizer business is more than 1 that is equal to 4.34. This ratio figures indicate that this business is very feasible to continue or develop in the future because this business gets a profit that can be said to be quite large. This advantage can be used for business development that can increase the worker's income.

The Break Even Point (BEP) analysis shows that this biourin business will benefit if this business produces or sells more than 98.96 liters per production process and vice versa, this business will get a loss if it sells less than that number.

Table 3 - Materials And Tools For Making Biourin Fertilizer

\begin{tabular}{|c|c|c|}
\hline Materials and tools needed & Amounts & Unit \\
\hline 100 liters of urine & 100 & Liter \\
5 liter MOL & 5 & Liter \\
Sere $1 / 2 \mathrm{~kg}$ & $1 / 2$ & $\mathrm{Kg}$ \\
Galangal $1 / 2 \mathrm{~kg}$ & $1 / 2$ & $\mathrm{Kg}$ \\
$1 / 2 \mathrm{~kg}$ of turmeric & $1 / 2$ & $\mathrm{Kg}$ \\
$1 / 2 \mathrm{~kg}$ of ginger & $1 / 2$ & $\mathrm{Kg}$ \\
$2 \mathrm{~kg}$ young bamboo shoots & 2 & 1 \\
Poly tank & 1 & Item \\
Suction pump (aerator) & 1 & Item \\
Gutter & 1 & Item \\
Water hose & 1 & Item \\
Paralon glue & 1 & Item \\
\hline
\end{tabular}

Source: Primary data processed, 2018.

Table 4 - Fixed Costs of Liquid Biourin Organic Fertilizer Business in Paya Tungel Village, Jagong Jeget District, Central Aceh

\begin{tabular}{|c|c|c|}
\hline Number & Amounts & Price \\
\hline Poly Tank Fiber Royal measuring 250 liters & 1 piece & 530.000 \\
Suction pump (aerator) & 1 piece & 350.000 \\
Gutter & $1 / 2$ rod & 35.000 \\
Water hose & 5 meters & 75.000 \\
Paralon glue & 1 piece & 10.000 \\
Plastic drum / water barrel & 1 piece & 80.000 \\
Knife & 1 piece & 20.000 \\
Miyako brand blender & 1 piece & 225.000 \\
Rubber strap & 1 meter & 1.000 \\
1 meter black plastic & 1 meter & 10.000 \\
Total & & 1.336 .000 \\
\hline
\end{tabular}

Source: Primary data processed, 2018.

Table 5 - Costs of Depreciating Liquid Biourin Organic Fertilizer in Paya Tungel Village, Jagong Jeget District, Central Aceh

\begin{tabular}{|c|c|c|c|c|}
\hline No & Equipment Type & $\begin{array}{l}\text { Equipment } \\
\text { Prices (Rp) }\end{array}$ & $\begin{array}{l}\text { Equipment } \\
\text { Prices (Rp) }\end{array}$ & $\begin{array}{c}\text { Depreciation } \\
\text { Value (Rp) }\end{array}$ \\
\hline 1 & Poly Tank Fiber Royal measuring 250 liters Suction pump (aerator) & 530.000 & 3 & 110.000 \\
\hline 2 & Gutter & 350.000 & 2 & 125.000 \\
\hline 3 & Water hose & 35.000 & 2 & 15.000 \\
\hline 4 & Paralon glue & 75.000 & 2 & 35.000 \\
\hline 5 & Plastic drum / water barrel & 10.000 & 1 & 2.000 \\
\hline 6 & Knife & 80.000 & 1 & 60.000 \\
\hline 7 & Miyako brand blender & 20.000 & 1 & 15.000 \\
\hline 8 & Rubber strap & 225.000 & 2 & 75.000 \\
\hline 9 & 1 meter black plastic & 1.000 & 1 & 100 \\
\hline 10 & Total & $\begin{array}{l}10.000 \\
1.336 .000\end{array}$ & 1 & $\begin{array}{l}8.000 \\
F C=445.100\end{array}$ \\
\hline
\end{tabular}

Source: Primary data processed, 2018. 
Table 6 - Variable Cost of Liquid Biourin Organic Fertilizer Business in Paya Tungel Village, Jagong Jeget District, Central Aceh

\begin{tabular}{|l|l|l|l|}
\hline No & Description & Amount & Price \\
\hline a. & liter MOL production costs & \\
& - Papaya & 2 pieces & 2.000 \\
& - Pineapple & 1 piece & 2.000 \\
& - Banana & 3 pieces & 3.000 \\
& -Coconut water & 2 liters & 10.000 \\
& - Rice washing water & 3 liters & 1.500 \\
& -Brown sugar & $1 \mathrm{~kg}$ & 10.000 \\
& Total & & 28.500 \\
b. & Biourin Production Costs & & \\
& -Lemongrass & $1 / 2 \mathrm{~kg}$ & 2.000 \\
& -Lengkuas & $1 / 2 \mathrm{~kg}$ & 2.000 \\
& -Turmeric & $1 / 2 \mathrm{~kg}$ & 2.000 \\
& -Ginger & $1 / 2 \mathrm{~kg}$ & 2.000 \\
& -Bung Bamboo & $2 \mathrm{~kg}$ & 10.000 \\
& Total & & 18.000 \\
& VC $=$ & & 46.500 \\
\hline
\end{tabular}

Source: Primary data processed, 2018.

$$
\mathrm{TC}=\mathrm{FC}+\mathrm{VC}=\mathrm{Rp} .491,600
$$

Reception:

$$
T R=P x Q=R p .6,000,000,-
$$

Where: TR = Acceptance; $\mathrm{P}=$ Biourin Price $(\mathrm{Rp}) ; \mathrm{Q}=$ Biourin Production (liters); TR $=\mathrm{Rp}$. 60,000 / liter x 100 liters

Profit:

$$
T C=T F C+T V C=1,382,500
$$

Then, profit $=$ Rp. $6,000,000-$ Rp. $1,382,500=$ Rp. 4,617,500.

Table 7 - Biourin Fertilizer Business Feasibility Analysis

\begin{tabular}{|c|c|}
\hline Type ofAnalysis & Value \\
\hline Revenue Per Cost Ratio & 4,34 \\
Break Even Point (Unit) & 98,96 liter \\
Break Even Point (Rupiah) & Rp. $1.346 .774,19$ \\
Return on Investment & $3,34 \%$ \\
\hline
\end{tabular}

\begin{tabular}{|c|c|c|}
\hline Calculation Element & Calculation Formula & Value \\
\hline Production results (liter / production process) & $a$ & 100 \\
\hline Raw material (liter / production process) & $b$ & 2 \\
\hline Labor (hours / production process) & $\mathrm{c}$ & 8 \\
\hline Conversion factor & $a / b=h$ & 50 \\
\hline Labor coefficient (\%) & $\mathrm{c} / \mathrm{b}=\mathrm{i}$ & 4 \\
\hline Product price (IDR / liter) & d & 60.000 \\
\hline Average wage (IDR / liter) & $\mathrm{e}$ & 50.000 \\
\hline Price of raw materials ( $\mathrm{Rp} /$ liter) & $f$ & 77.000 \\
\hline Other inputs (Rp / liter) & $g$ & 0 \\
\hline Production Value (IDR / liter) & $h \times d=j$ & 3.000 .000 \\
\hline a. Added value (Rp / liter) & $j-f-g=k$ & 2.923 .000 \\
\hline b. Added Value Ratio (\%) & $\mathrm{k} / \mathrm{j}$ & 0,974 \\
\hline a. Labor benefits (Rp) & $\mathrm{i} x \mathrm{e}=\mathrm{m}$ & 200.000 \\
\hline b. Labor portion (\%) & $\mathrm{m} / \mathrm{k}$ & 0,0684 \\
\hline a. Benefits (IDR / liter) & $\mathrm{k}-\mathrm{m}=\mathrm{o}$ & 2.723 .000 \\
\hline b. Profit Level (\%) & $\mathrm{o} / \mathrm{k}$ & 0,9315 \\
\hline Processing margin & $j-f=q$ & 2.923 .000 \\
\hline
\end{tabular}

Source: Primary data processed, 2018.

Table 8 - Analysis Of Added Value In Biourin Fertilizers Using Hayami Method

Source: Primary data processed, 2017. 
In each production process, the amount of profit obtained is $\mathrm{Rp} .4,617,500$, - and the total investment is Rp. $1,382,500$. Of this amount, the ROI value is $3.34 \%$. This means that every 1 unit of capital issued by this biourin manufacturing business will get a capital return of $3.34 \%$ of the issued capital. The amount of ROI value from the results of this calculation can be a consideration for investors to invest in this business and can be used as business expansion.

From the calculation results obtained the ratio of value added to biourin products of 0.974 or $97.4 \%$. This value indicates that the biourin business is classified as high in accordance with the indicator that if the value added ratio is greater than $40 \%$ then the business is said to have high added value in each liter of its product.

\section{REFERENCES}

1. Hayami, $\mathrm{Y}$ et al. 1987. Agricultural Marketing and Processing in Upland Java, A Prespective From Sinda Village. Coarse Grains Pulses Roots and Tuber Center (CGPRTC). Bogor. 75 hal.

2. Madjid, A. 2011. Dasar dasar ulmu tanah. PT. Medityama Sarana Perkasa, Jakarta.

3. Marshall, Catherine and Rossman, B. Gretchen. (1989). Designing qualitative research. London, New Neldi: Sage Publications.

4. Rahardi, F. Dkk. 1998. Agribisnis perikanan. Penebar swadaya. Jakarta.

5. Soekartawi. 1995. Analisis uaha tani. UI Press. Jakarta.

6. Sutanto, R. 2002. Pertanian Organik menuju pertanian alternatif dan berkelanjutan. Kanisius. Yogyakarta. 